\title{
AGRESSIVENESS AND BIOCONTROL OF Rosellinia bunodes IN POPLAR
}

\author{
Heloisa Thomazi Kleina ${ }^{1 *}$, Álvaro Figueredo dos Santos ${ }^{2}$, Henrique da Silva Silveira Duarte ${ }^{3}$, Edilene \\ Buturi Machado ${ }^{4}$ \\ ${ }^{1 *}$ Universidade Federal do Paraná, Departamento de Fitotecnia e Fitossanidade, Curitiba, Paraná, Brasil - \\ heloisathomazi@gmail.com (*AUTOR PARA CORRESPONDÊNCIA) \\ ${ }^{2}$ Empresa Brasileira de Pesquisa Agropecuária, Embrapa Florestas, Colombo, Paraná, Brasil - \\ alvaro.santos@embrapa.br \\ ${ }^{3}$ Universidade Federal do Paraná, Departamento de Fitotecnia e Fitossanidade, Curitiba, Paraná, Brasil - \\ henriqueduarte@ufpr.br \\ ${ }^{4}$ Swedish Match do Brasil, Curitiba, Paraná, Brasil - edilene.buturi.machado@gmail.com \\ Received for publication: 23/04/2018 - Accepted for publication: 18/10/2018
}

\begin{abstract}
Resumo
Agressividade e biocontrole de Rosellinia bunodes em álamo. A roseliniose, causada pelo fungo Rosellinia bunodes, tem ganhado destaque devido a incidência em plantios comerciais de espécies florestais, como o álamo. Em razão da ausência de produtos fitossanitários registrados para esta cultura no Brasil, o controle cultural, muitas vezes ineficiente, torna-se a única opção para o controle desta doença. Na busca de soluções deste problema, o controle biológico vem de encontro com as necessidades da implantação de um sistema mais sustentável. Objetivou-se com este trabalho avaliar a agressividade de isolados de $R$. bunodes em álamo e a capacidade antagônica in vitro e in vivo de isolados de Trichoderma spp. no controle desse fitopatógeno. Para o ensaio de agressividade, mudas sadias de álamo foram plantadas em substrato inoculado com nove isolados de $R$. bunodes. Os testes de antagonismo em confrontação direta, produção de compostos voláteis e não voláteis foram realizados entre 30 isolados de Trichoderma spp. e o isolado R2 de R. bunodes. No teste in vivo, os tratamentos consistiram em diferentes datas de plantios das mudas em substrato infestado com o fungo antagonista e o fitopatógeno. Os isolados R2, R3, R3A, R6 e R8 de $R$. bunodes se mostraram mais agressivos que os demais. Dos 30 isolados de Trichoderma spp., doze podem ser considerados potenciais agentes de biocontrole, devido à alta capacidade competitiva e supressão do crescimento micelial de R. bunodes. O maior o tempo de exposição entre o patógeno e o agente antagonista no substrato apresentou a menor incidência da roseliniose em álamo.
\end{abstract}

Palavras-chave: controle biológico, podridão radicular, Trichoderma.

\begin{abstract}
The Rosellinia root rot, caused by the fungus Rosellinia bunodes, has gained prominence due to the incidence in commercial plantations of forest species, such as poplar. Due to the absence of phytosanitary products registered for this crop in Brazil, cultural control, often inefficient, becomes the only option for the control of this disease. In the search for solutions to this problem, biological control meets the needs of implementing a more sustainable system. The objective of this work was to evaluate the aggressiveness of $R$. bunodes isolates in poplar and the antagonistic capacity in vitro and in vivo of Trichoderma spp. in control of this phytopathogen. For the aggressiveness test, healthy poplar seedlings were planted on substrate inoculated with nine $R$. bunodes isolates. The tests of antagonism in direct confrontation, production of volatile and non-volatile compounds were performed among 30 isolates of Trichoderma spp. and $R$. bunodes isolate $\mathrm{R} 2$. In the in vivo test, the treatments consisted of different planting dates of the seedlings infested with the antagonist fungus and the phytopathogen. R. bunodes isolates R2, R3, R3A, R6 and R8 were more aggressive than the others. From 30 isolates of Trichoderma spp., 12 may be considered as potential biocontrol agents due to the high competitive capacity and suppression of mycelial growth of $R$. bunodes. The longer exposure time between the pathogen and the antagonist on the substrate decreased the incidence of Rosellinia root rot in poplar.
\end{abstract}

Key words: biological control, root rot, Trichoderma.

\section{INTRODUCTION}

Poplar (Populus deltoides Bartr. ex Marsh.) is a forest species cultivated worldwide due to the high quality of its wood. In the southern region of Brazil, poplar plantations are located in the Iguaçu River Valley (Porto União, SC, Paula Freitas and União da Vitória, PR) (SANTOS et al., 2010), which production is fully destined to the manufacture of matchsticks (MAY DE MIO; RUARO, 2008).

Poplar clones are extremely demanding in cultural and phytosanitary treatments (MAY DE MIO; AMORIM, 2000), which increases the production costs of the planted forests. The main diseases of this crop are

FLORESTA, Curitiba, PR, v. 49, n. 3, p. 439 - 448, jul/set 2019.

Kleina, H. T. et.al.

ISSN eletrônico 1982-4688

DOI: $10.5380 /$ rf.v49 i3.59075 
rust (Melampsora medusae Thuem.) (MAY DE MIO; RUARO, 2008) and septoriosis (Septoria musiva Peck.) (SANTOS et al., 2010). However, since 2010, mortality of trees in commercial plantations caused by the fungus Rosellinia bunodes (Berk. et Br.) Sacc. has been observed in the state of Paraná (SANTOS et al., 2017).

Phytopathogenic fungi of the genus Rosellinia are responsible for considerable damage in many cultivated species, especially perennial tree species such as cocoa, coffee and rubber trees (SIVANESAN; HOLLIDAY, 1972). The main symptoms of Rosellinia in poplar are the yellowing and wilting of leaves, the drying of branches and the premature plants death (SANTOS et al., 2017), which occurs as a consequence of the involvement of the entire root system by the fungus colonization in these areas, reducing and / or impairing the sap flow to shoots. Since it is relatively new pathosystem in the country, there are no studies regarding the aggressiveness of Brazilian R. bunodes isolates in poplar. Aggressiveness is associated with the speed with which the disease symptoms manifest. In the case of Rosellinia, the high genetic heterogeneity of this fungus can cause aggressiveness to be a variable among species and even among isolates of the same species (RUANO-ROSA et al., 2010).

The easy dissemination, the wide range of hosts and the lack of knowledge about the characteristics intrinsic to the pathogen make this disease a threat to poplar trees due to the absence of phytosanitary products registered for this crop in Brazil. The use of cultural control techniques, such as eradication of diseased plants, removal of decomposing woody residues and soil solarization (SZTEJNBERG et al., 1987), are the only control options; however, these practices do not provide efficiency in the reduction of the inoculum potential in infested soils.

In the search for an effective control method, the use of alternative techniques, such as biological control, meets the needs of this pathosystem. Given the above, special attention has been given to this research line, in which microorganisms are tested as potential biocontrol agents for plant diseases. The fungus Trichoderma spp. is one of the most researched fungi in Brazil, and has potential to be used on a large scale (SAITO et al., 2009) due to its desirable qualities, such as behavioral versatility, stimulating parasitism and antibiosis processes and competition against several plant pathogens (VINALE et al., 2008) (KUMAR, 2013). Thus, this work aimed to evaluate the aggressiveness of $R$. bunodes isolates and the in vitro and in vivo antagonistic capacity of Trichoderma spp. isolates for the Rosellinia root rot control in poplar.

\section{MATERIAL AND METHODS}

Experiments were conducted at the Laboratory of Forest Pathology of the Brazilian Agricultural Research Company (Embrapa Florestas), located at the municipality of Colombo, Paraná, Brazil. Pure R. bunodes and Trichoderma spp. cultures are deposited and encoded in the fungi collection of Embrapa Florestas, Colombo, Paraná, Brazil.

\section{Aggressiveness of Rosellinia bunodes isolates in poplar}

The experiment was conducted in a completely randomized design with ten treatments (nine $R$. bunodes isolates and one control) and four replicates, each replicate composed of two seedlings. Nine R. bunodes isolates (R1, R2, R3, R3A, R4, R5, R6, R7 and R8) were collected from adult poplar tree roots with Rosellinia root rot symptoms in commercial plantation located at the municipality of Paula Freitas, Paraná, Brazil.

For inoculum production, $80 \mathrm{~g}$ of sorghum grains and $40 \mathrm{~mL}$ of distilled water were added in clear glass flasks ( $500 \mathrm{~mL}, 14.5 \mathrm{~cm}$ in height and $5 \mathrm{~mm}$ in diameter) and autoclaved at $120^{\circ} \mathrm{C}$ for 30 minutes. Flasks received seven $8 \mathrm{~mm}$ diameter discs of BDA (potato-dextrose-agar) culture medium with active mycelial growth from each of the nine $R$. bunodes isolates. This material was incubated at $24{ }^{\circ} \mathrm{C} \pm 2{ }^{\circ} \mathrm{C}$ in the dark for 17 days and then mixed with commercial substrate (Plantmax Florestal®), in the proportion of $1 \mathrm{~kg}$ of substrate to $32 \mathrm{~g}$ of inoculated sorghum grains. The mixture was conditioned in plastic containers with capacity of $1.7 \mathrm{~L}$ (height: $20 \mathrm{~cm}$; diameter: $12 \mathrm{~cm}$ ), then poplar seedlings at six months of age were transplanted. Uninoculated substrate was used in control treatment.

Incidence evaluation was performed at 7, 14, 21, 28, 35, 42 and 49 days after inoculation, considering diseased plants those that had some of chlorosis and necrosis symptoms, wilt or death. From incidence data, the area under the disease progress curve (AUDPC) (SHANER; FINNEY, 1977) was calculated. Data variance homogeneity was verified by the Bartlett test and the error normality by the Kolmogorov-Smirnov test. The AUDPC values of each treatment were submitted to analysis of variance and averages were compared by the Tukey test at $5 \%$ of probability using the R software (R DEVELOPMENT CORE TEAM, 2013).

\section{In vitro biocontrol of Rosellinia bunodes in poplar}

The experimental design was completely randomized distributed in 31 treatments (30 Trichoderma spp. 
isolates and control) with three replicates, each replicate represented by a Petri dish. The 30 Trichoderma spp. isolates (Table 1) were transferred to Petri dishes with BDA culture medium and incubated in a BOD-type growth chamber at $24^{\circ} \mathrm{C}$ with 12 -hour photoperiod for five days. R2 isolate ( $R$. bunodes), considered to be one of the most aggressive isolate in the aggressiveness test, was transferred to BDA culture medium and incubated in a BODtype growth chamber at $24^{\circ} \mathrm{C}$ in the dark for 10 days.

For the antagonistic activity (dual culture assay), $5 \mathrm{~mm}$ diameter discs with active mycelial growth of R2 $R$. bunodes isolates were transferred to Petri dishes four days earlier than Trichoderma spp. isolates due to the difference in the mycelial growth speed of the pathogen in relation to the antagonist. Fungi were oppositely arranged on dishes, both remaining approximately $2.0 \mathrm{~cm}$ away from dish extremities. Control consisted solely of deposition of $R$. bunodes isolate discs. After pairing, dishes were maintained in a BOD type incubator at temperature of $24^{\circ} \mathrm{C}$ with 12 -hour photoperiod for nine days.

For the trial of volatile compounds release by Trichoderma spp., the methodology described by Mariano (1993) was used. The method described by Michereff et al. (1993) was used to test the production of nonvolatile metabolites by the antagonist fungus. The control of both tests received only phytopathogen mycelial discs.

The antagonistic capacity of Trichoderma spp. isolates was evaluated at the seventh (volatile compounds release), ninth (direct confrontation) and tenth day (nonvolatile compounds release) after the experiments installation. Evaluations consisted in the measurement of two diametrically opposed measurements of the phytopathogen colony with the aid of a digital caliper. From the mean of the two measurements, the pathogen growth inhibition percentage was calculated using the formula proposed by Edginton et al. (1971). Data variance homogeneity was verified by the Bartlett test and the error normality by the Kolmogorov-Smirnov test. Data were submitted to analysis of variance and means were compared by the Scott-Knott test at 5\% probability using the R software (R DEVELOPMENT CORE TEAM, 2013).

Table 1. Origin of Trichoderma spp. isolates. Colombo (PR), Brazil, 2014.

Tabela 1. Procedência dos isolados de Trichoderma spp. Colombo (PR), Brasil, 2014.

\begin{tabular}{cccc}
\hline ISOLATE & HOST & PLANT PART & ORIGIN \\
\hline 100 & Poplar & Root & Paula Freitas-PR \\
103 & Pupunha & Root & Colombo-PR \\
104 & Pupunha & Root & Colombo-PR \\
105 & Pupunha & Root & Colombo-PR \\
106 & Pupunha & Stem collar & Colombo-PR \\
108 & Pupunha & Root & Colombo-PR \\
109 & Pupunha & Root & Colombo-PR \\
111 & Pupunha & Root & Colombo-PR \\
112 & Pupunha & Seed & Colombo-PR \\
113 & Pupunha & Root & Colombo-PR \\
114 & Pupunha & Root & Colombo-PR \\
115 & Pupunha & Root & Colombo-PR \\
116 & Pupunha & Root & Colombo-PR \\
118 & Pupunha & Root & Colombo-PR \\
119 & Pupunha & Root & Colombo-PR \\
AR & Araucaria & Root & Colombo-PR \\
B1R1 & Pinus & Root & Colombo-PR \\
B2R1 & Pinus & Root & Colombo-PR \\
B2R2 & Pinus & Root & Colombo-PR \\
BR1 & Pinus & Root & Colombo-PR \\
BR2 & Pinus & Root & Colombo-PR \\
LPF8 & Pinus & Root & Guarapuava-PR \\
LPFE 3 & Pinus & Root & Guarapuava-PR \\
PR3 & Pinus & Root & Guarapuava-PR \\
SP4 & Araucaria & Root & Guarapuava-PR \\
TR0506 & Pinus & Root & Guarapuava-PR \\
TRB1 & Pinus & Root & Guarapuava-PR \\
TRB2 & Pinus & Root & Guarapuava-PR \\
TRCO & Coconut & Fruit & Seed \\
TRE & Pinus & & \\
& & & Colombo-PR \\
\hline
\end{tabular}

\section{In vivo biocontrol of Rosellinia bunodes in poplar}

For this assay, AR isolate was selected as having one of the best performances in in vitro tests. The DNA of AR isolate colonies was extracted and used for amplification of the rDNA ITS region by PCR (Polymerase

FLORESTA, Curitiba, PR, v. 49, n. 3, p. 439 - 448, jul/set 2019.

Kleina, H. T. et.al.

ISSN eletrônico 1982-4688

DOI: $10.5380 /$ rf.v49 i3.59075 
Chain Reaction), using ITS1 and ITS4 primers described by White et al. (1990). PCR products (456 bp) were sequenced and compared in GenBank using the Basic Local Alignment Search Tool (BLAST) software. Sequences were $100 \%$ similar with Trichoderma asperellum Samuels, Lieckf. \& Nirenberg (MURALI SANKAR et al., 2018). The experiment was conducted in a completely randomized design with ten replicates, each replicate composed of one seedling. Treatments consisted of different planting dates, arranged as follows: Control: seedlings planted in substrate containing only $R$. bunodes isolate; Treatment 1 : seedlings planted on the same day as the addition of $R$. bunodes isolate and T. asperellum isolate to the substrate; Treatment 2: seedlings planted seven days after the addition of $R$. bunodes isolate and T. asperellum isolate to the substrate; Treatment 3: seedlings planted 14 days after the addition of the $R$. bunodes isolate and $T$. asperellum isolate to the substrate.

The AR isolate of T. asperellum was transferred to Petri dishes with BDA culture medium and incubated in a BOD-type growth chamber at $24^{\circ} \mathrm{C}$ with a 12 -hour photoperiod for five days. The $\mathrm{R} 2$ isolate of $R$. bunodes, considered one of the most aggressive in the aggressiveness test, was transferred to BDA culture medium and incubated in a BOD-type growth chamber at $24^{\circ} \mathrm{C}$ in the dark for 10 days. The production of inoculum from $R$. bunodes and T. asperellum isolates, the proportion of inoculum/substrate mixture and the transplanting of poplar seedlings followed the same methodology applied to the aggressiveness assay.

The determination of the conidia concentration of $T$. asperellum isolates was carried out by weighing $1 \mathrm{~g}$ of sorghum grains colonized with the antagonist diluted in $10 \mathrm{~mL}$ of sterilized deionized water. An aliquot of $1 \mathrm{ml}$ of suspension was added to the Neubauer Chamber, obtaining concentration of $7 \times 10^{6} \mathrm{~T}$. asperellum conidia/ml. The final concentration obtained was $2.24 \times 10^{9} \mathrm{~T}$. asperellum conidia/32 $\mathrm{g}$ of sorghum grains colonized with the antagonist.

Incidence evaluations were performed at 7, 14, 21, 28 and 35 days after substrate infestation, considering diseased plants those showing some of chlorosis and necrosis symptoms, wilt or death. From the incidence data, the area under the disease progress curve (AUDPC) was calculated (SHANER; FINNEY, 1977). AUDPC was then divided by the duration of the epidemic into days and multiplied by 100 to obtain the area under the relative disease progress curve (rAUDPC) proposed by Fry (1978). Data variance homogeneity was verified by the Bartlett test and the error normality by the Kolmogorov-Smirnov test. The rAUDPC values of each treatment were submitted to analysis of variance and the means were compared by the Tukey test at $5 \%$ probability, using the $\mathrm{R}$ software (R DEVELOPMENT CORE TEAM, 2013).

\section{RESULTS}

\section{Aggressiveness of Rosellinia bunodes isolates in poplar}

The nine $R$. bunodes isolates tested can be considered phytopathogenic, since all isolates caused root rot in poplar seedlings (Figure 1). R2, R3, R3A, R6 and R8 isolates were considered the most aggressive, presenting the largest areas under the disease progress curve. R7 isolate was considered the least aggressive (Figure 2).

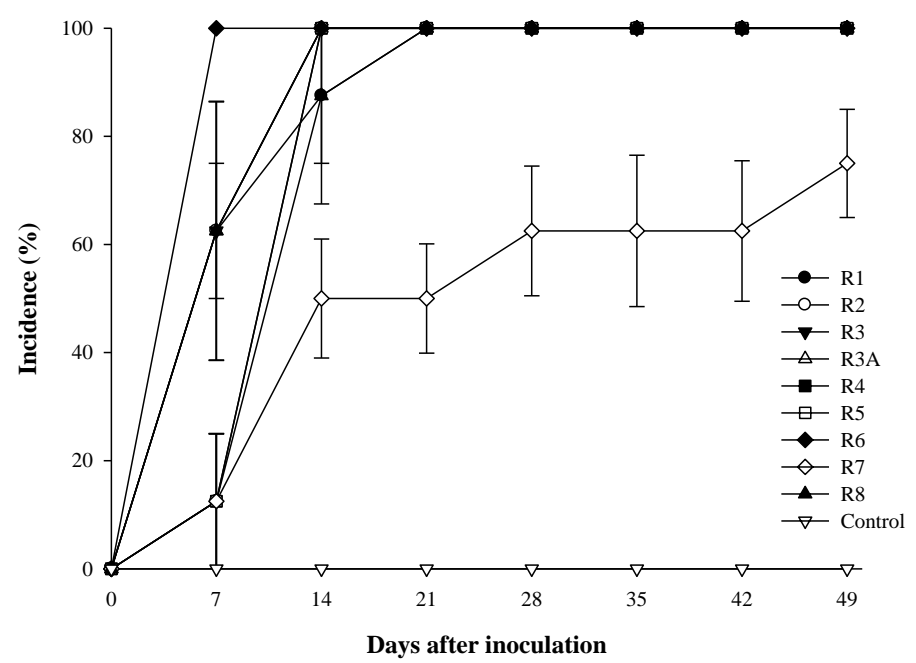

Figure 1. Incidence of Rosellinia rot root in poplar seedlings inoculated with different Rosellinia bunodes isolates. Colombo (PR), Brazil, 2014.

Figura 1. Incidência da roseliniose em mudas de álamo inoculadas com diferentes isolados de Rosellinia bunodes. Colombo (PR), Brasil, 2014. 


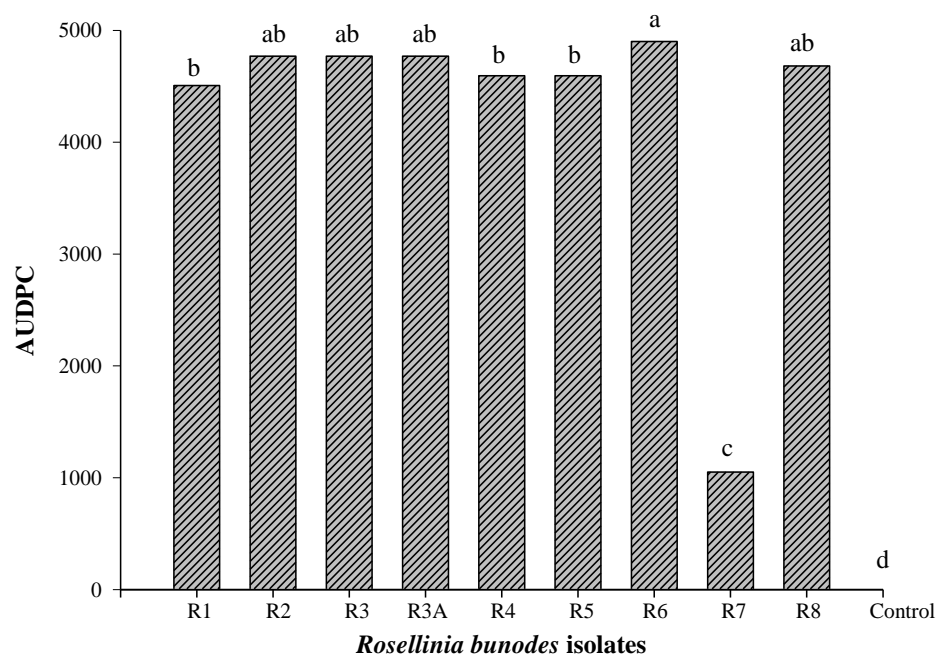

*Means followed by the same letter do not differ statistically from each other by the Tukey test at the $5 \%$ probability level.

Figure 2. Area under the disease progress curve (AUDPC) for nine Rosellinia bunodes isolates inoculated on poplar seedlings at six months of age. Colombo (PR), Brazil, 2014.

Figura 2. Área abaixo da curva de progresso da doença (AACPD) para nove isolados de Rosellinia bunodes inoculados em mudas de álamo com seis meses de idade. Colombo (PR), Brasil, 2014.

\section{In vitro biocontrol of Rosellinia bunodes in poplar}

Among the three methodologies applied to evaluate the inhibition of the mycelial growth of R. bunodes, the volatile compounds release technique showed average reduction of $59.54 \%$, followed by $27.04 \%$ and $24.45 \%$, for paired cultures and nonvolatile compounds release tests, respectively.

In the direct confrontation test (pairing), the thirty isolates of Trichoderma spp. tested inhibited the mycelial growth of the pathogen, not statistically differing from each other, except for the TR0506 isolate, which presented lower mean inhibition $(10.22 \%)$.

For the volatile compound release test, the 109, 116, 119, TR0506 and TRB2 isolates were less efficient in the control, reaching mean inhibition values of $26.1 \%$, well below that obtained with the remaining isolates (66.2\%). For the nonvolatile compounds release test, 14 Trichoderma spp. isolates $(103,104,105,108,109,112$, 113, 115, 119, AR, LPF8, SP4, TRB1 and TRE) showed inhibition percentage greater than 33\%. However, the 106, 111, 114, B1R1, BR2, LPFE3, TR0506, TRB2, TRCO isolates and control were not able to reduce the mycelial growth of $R$. bunodes, exhibiting no inhibition $(0 \%)$ using the same evaluation method.

Twelve Trichoderma spp. isolates (103, 104, 108, 112, 113, 115, 119, AR, LPF8, SP4, TRB1 and TRE) can be considered potential biocontrol agents due to their high competitive capacity and suppression of the $R$. bunodes mycelial growth, according to the three methodologies applied (Table 2).

Table 2. Percentage inhibition (\%) of Rosellinia bunodes mycelial growth by the paired cultures method, volatile compounds and nonvolatile compounds release using Trichoderma spp. isolates. Colombo (PR), Brazil, 2014. spp.

Tabela 2. Percentagem de inibição (\%) do crescimento micelial de Rosellinia bunodes pelo método de culturas pareadas, liberação de compostos voláteis e compostos não voláteis utilizando isolados de Trichoderma spp. Colombo (PR), Brasil, 2014.

FLORESTA, Curitiba, PR, v. 49, n. 3, p. 439 - 448, jul/set 2019 


\begin{tabular}{|c|c|c|c|}
\hline \multirow{2}{*}{ Rosellinia bunodes $x$ Trichoderma spp. } & \multicolumn{3}{|c|}{ Inhibition (\%) } \\
\hline & Pairing & Volatile compounds & Nonvolatile compounds \\
\hline R2 x R2 (Control) & $0.00 \mathrm{c}$ & $0.00 \mathrm{c}$ & $0.00 \mathrm{~b}$ \\
\hline $\mathrm{R} 2 \times 100$ & $33.09 \mathrm{a}$ & $54.48 \mathrm{a}$ & $11.44 \mathrm{~b}$ \\
\hline $\mathrm{R} 2 \times 103$ & $33.30 \mathrm{a}$ & $60.87 \mathrm{a}$ & $52.81 \mathrm{a}$ \\
\hline $\mathrm{R} 2 \times 104$ & $32.10 \mathrm{a}$ & $59.40 \mathrm{a}$ & $48.21 \mathrm{a}$ \\
\hline $\mathrm{R} 2 \times 105$ & $23.26 \mathrm{a}$ & $73.40 \mathrm{a}$ & $38.44 \mathrm{a}$ \\
\hline $\mathrm{R} 2 \times 106$ & $26.77 \mathrm{a}$ & $66.42 \mathrm{a}$ & $0.00 \mathrm{~b}$ \\
\hline $\mathrm{R} 2 \times 108$ & $33.69 \mathrm{a}$ & $52.18 \mathrm{a}$ & $41.00 \mathrm{a}$ \\
\hline $\mathrm{R} 2 \times 109$ & $29.79 \mathrm{a}$ & $28.12 b$ & $46.88 \mathrm{a}$ \\
\hline $\mathrm{R} 2 \times 111$ & $22.94 \mathrm{a}$ & $69.88 \mathrm{a}$ & $0.00 \mathrm{~b}$ \\
\hline $\mathrm{R} 2 \times 112$ & $24.79 \mathrm{a}$ & $73.00 \mathrm{a}$ & $48.20 \mathrm{a}$ \\
\hline $\mathrm{R} 2 \times 113$ & $24.13 \mathrm{a}$ & $66.70 \mathrm{a}$ & $33.40 \mathrm{a}$ \\
\hline $\mathrm{R} 2 \times 114$ & $24.20 \mathrm{a}$ & $67.70 \mathrm{a}$ & $0.00 \mathrm{~b}$ \\
\hline $\mathrm{R} 2 \times 115$ & $25.58 \mathrm{a}$ & $76.66 \mathrm{a}$ & $51.40 \mathrm{a}$ \\
\hline $\mathrm{R} 2 \times 116$ & $26.76 \mathrm{a}$ & $15.52 \mathrm{c}$ & $0 \mathrm{~b}$ \\
\hline $\mathrm{R} 2 \times 118$ & $18.82 \mathrm{a}$ & $46.53 \mathrm{a}$ & $9.74 \mathrm{~b}$ \\
\hline $\mathrm{R} 2 \times 119$ & $24.56 \mathrm{a}$ & $38.05 \mathrm{~b}$ & $36.47 \mathrm{a}$ \\
\hline $\mathrm{R} 2 \times \mathrm{AR}$ & $24.44 \mathrm{a}$ & $68.68 \mathrm{a}$ & $60.94 \mathrm{a}$ \\
\hline $\mathrm{R} 2 \times \mathrm{B} 1 \mathrm{R} 1$ & $33.66 \mathrm{a}$ & $69.19 \mathrm{a}$ & $0.00 \mathrm{~b}$ \\
\hline $\mathrm{R} 2 \times \mathrm{B} 2 \mathrm{R} 1$ & $27.16 \mathrm{a}$ & $74.62 \mathrm{a}$ & $12.45 \mathrm{~b}$ \\
\hline $\mathrm{R} 2 \times \mathrm{B} 2 \mathrm{R} 2$ & $29.26 \mathrm{a}$ & $72.77 \mathrm{a}$ & $5.46 \mathrm{~b}$ \\
\hline $\mathrm{R} 2 \times \mathrm{BR} 1$ & $29.98 \mathrm{a}$ & $64.48 \mathrm{a}$ & $6.28 \mathrm{~b}$ \\
\hline $\mathrm{R} 2 \times \mathrm{BR} 2$ & $22.83 \mathrm{a}$ & $64.79 \mathrm{a}$ & $0.00 \mathrm{~b}$ \\
\hline R2 x LPF8 & $28.83 \mathrm{a}$ & $67.50 \mathrm{a}$ & $48.10 \mathrm{a}$ \\
\hline R2 x LPFE3 & $23.17 \mathrm{a}$ & $60.37 \mathrm{a}$ & $0.00 \mathrm{~b}$ \\
\hline R2 x PR3 & $29.08 \mathrm{a}$ & $63.69 \mathrm{a}$ & $22.38 \mathrm{a}$ \\
\hline $\mathrm{R} 2 \times \mathrm{SP} 4$ & $28.49 \mathrm{a}$ & $63.30 \mathrm{a}$ & $60.41 \mathrm{a}$ \\
\hline $\mathrm{R} 2 \times \mathrm{TR} 0506$ & $10.22 \mathrm{~b}$ & $26.32 \mathrm{~b}$ & $0.00 \mathrm{~b}$ \\
\hline $\mathrm{R} 2 \times \mathrm{TRB} 1$ & $25.47 \mathrm{a}$ & $63.26 \mathrm{a}$ & $38.68 \mathrm{a}$ \\
\hline $\mathrm{R} 2 \times \mathrm{TRB} 2$ & $31.73 \mathrm{a}$ & $22.89 \mathrm{~b}$ & $0.00 \mathrm{~b}$ \\
\hline $\mathrm{R} 2 \times \mathrm{TRCO}$ & $34.54 \mathrm{a}$ & $79.00 \mathrm{a}$ & $0.00 \mathrm{~b}$ \\
\hline R2 $x$ TRE & $28.73 \mathrm{a}$ & $76.57 \mathrm{a}$ & $60.81 \mathrm{a}$ \\
\hline Mean inhibition (\%) & 27.04 & 59.54 & 24.45 \\
\hline
\end{tabular}

* Means followed by the same letter do not differ statistically from each other by the Scott-Knott test at the 5\% probability level.

\section{In vivo biocontrol of Rosellinia bunodes in poplar}

At 21 days after substrate infestation (=21 days after seedlings planting), poplar seedlings were planted concomitantly with the inoculation of the phytopathogen to the substrate (control) and seedlings that were planted at the time of substrate infestation with the phytopathogen and the biocontrol agent (treatment 1) presented high incidence values (90\% and 60\%, respectively). On the other hand, at 28 days after substrate infestation, seedlings planted 7 days after substrate infestation with $R$. bunodes and T. asperellum (treatment 2) presented incidence of $50 \%$. In seedlings planted 14 days after substrate infestation with R. bunodes and T. asperellum (treatment 3 ), the incidence was $20 \%$ at 35 days after substrate infestation (Figure 3).

The highest relative AUDPC was verified for control (88.0) and treatment 1 (74.0), statistically differing from treatments 2 and 3, the latter being considered the most efficient in the Rosellinia root rot control in poplar (Figure 4).

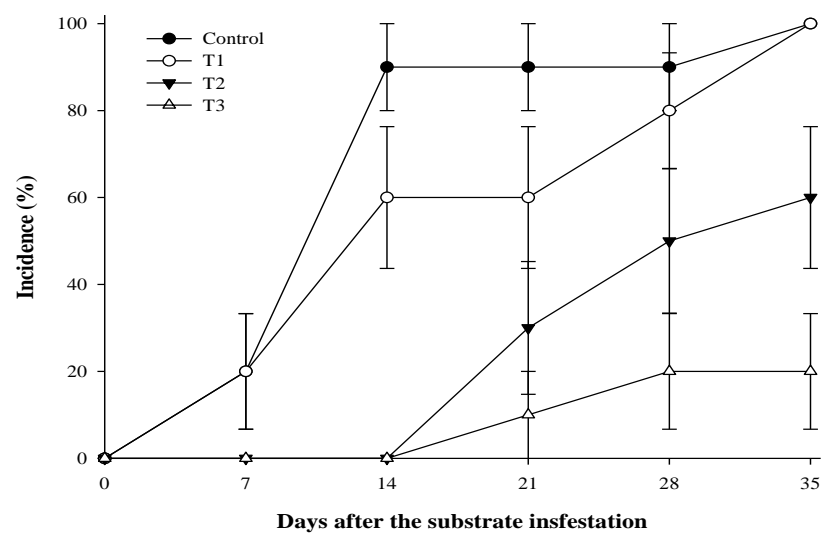

FLORESTA, Curitiba, PR, v. 49, n. 3, p. 439 - 448, jul/set 2019 
Figure 3. Rosellinia root rot incidence (\%) in poplar seedlings kept under different treatments: Control: seedlings planted in substrate containing only $R$. bunodes isolate; Treatment 1: seedlings planted on the same day as the addition of the R. bunodes isolate and T. asperellum isolate to the substrate; Treatment 2: seedlings planted 7 days after the addition of $R$. bunodes isolate and $T$. asperellum isolate to the substrate; Treatment 3: seedlings planted 14 days after the addition of $R$. bunodes isolate and $T$. asperellum isolate to the substrate. Bars represent the standard error. Colombo (PR), Brazil, 2014.

Figura 3. Incidência (\%) da roseliniose em mudas de álamo mantidas sob diferentes tratamentos: Testemunha: mudas plantadas em substrato contendo somente o isolado de $R$. bunodes; Tratamento 1: mudas plantadas no mesmo dia da adição do isolado de $R$. bunodes e do isolado de T. asperellum ao substrato; Tratamento 2: mudas plantadas 7 dias após a adição do isolado de $R$. bunodes e do isolado de $T$. asperellum ao substrato; Tratamento 3: mudas plantadas 14 dias após a adição do isolado de $R$. bunodes e do isolado de T. asperellum ao substrato. As barras representam o erro padrão. Colombo (PR), Brasil, 2014

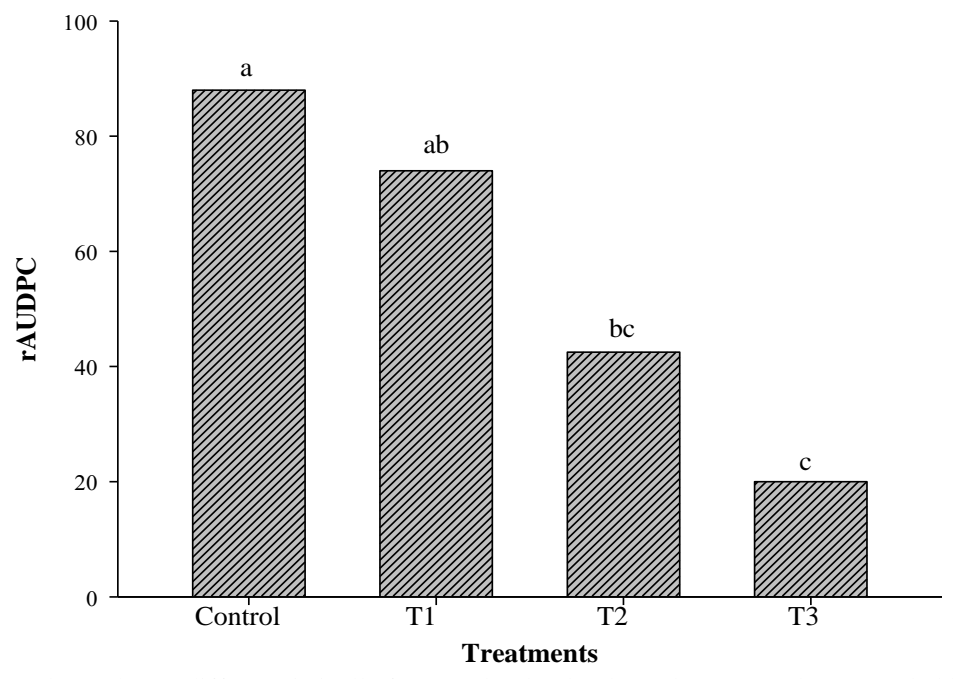

*Means followed by the same letter do not differ statistically from each other by the Tukey test at the 5\% probability level. rAUDPC: Relative area under the disease progress curve. Control: seedlings planted in substrate containing only R. bunodes isolate; Treatment 1: seedlings planted on the same day as the addition of the $R$. bunodes isolate and T. asperellum isolate to the substrate; Treatment 2: seedlings planted 7 days after the addition of $R$. bunodes isolate and T. asperellum isolate to the substrate; Treatment 3: seedlings planted 14 days after the addition of $R$. bunodes isolate and T. asperellum isolate to the substrate. Bars represent the standard error. Colombo (PR), Brazil, 2014.

Figure 4. Relative area under the disease progress curve (rAUDPC) for poplar seedlings (with six months of age) in substrate infested with Rosellinia bunodes and Trichoderma asperellum. Colombo (PR), Brazil, 2014.

Figura 4. Área abaixo da curva de progresso da doença relativa (AACPDR) para mudas de álamo (com seis meses de idade) em substrato infestado com Rosellinia bunodes e Trichoderma asperellum. Colombo (PR), Brasil, 2014.

\section{DISCUSSION}

The results of the present study are relevant since they showed differences in the aggressiveness of $R$. bunodes isolates to poplar and evidenced the suppression of this pathogen in the presence of Trichoderma spp. isolates.

The aggressiveness variation is often evaluated in phytopathology studies to know the variability regarding the capacity of different isolates to cause different disease intensities. Thus, understanding the aggressiveness of pathogens is critical to improve the effectiveness of control practices (LEHNER et al., 2016), particularly regarding the use of phytopathogen suppression strategies by biological methods.

Potential biocontrol agents should be excellent colonizers and persist as root endophytes (DOORNBOS et al., 2011). The search for isolates in root regions of healthy plants among diseased plants of the same species is considered an effective way of prospection, since the chances of success are greater if pathogen and antagonist occupy the same ecological niche. However, in this work it was possible to verify that even Trichoderma spp. isolates being from rhizospheres of other forest crops, such as araucaria, pinus and pupunha, presented high growth inhibition rates.

Comparing the results obtained in in vitro control methodologies, the variability in efficiency for the

FLORESTA, Curitiba, PR, v. 49, n. 3, p. 439 - 448, jul/set 2019.

Kleina, H. T. et.al.

ISSN eletrônico 1982-4688

DOI: $10.5380 /$ rf.v49 i3.59075 
same group of Trichoderma spp. isolates in the control of $R$. bunodes may be associated with their origin. These isolates are composed of several genotypes with different levels of essential activities, such as growth and sporulation, which in turn directly affect the biological control mechanisms (RUANO-ROSA et al., 2010).

Inhibition of phytopathogen growth in cultures paired with antagonist agents is mainly based on competition for space, light and nutrients. For Pasini et al. (2016), the growth of $R$. necatrix decreased after the second day of pairing with $T$. atroviride isolate, and at day 7, the inhibition percentage of the phytopathogen radial growth reached 54\%. In a study developed by Ruano-Rosa et al. (2010), thirty Trichoderma spp. isolates with inhibition levels below $40 \%$ for the mycelial growth of $R$. necatrix (Rn 400) by the method of paired cultures were identified. These isolates, even presenting relatively low values, were considered as potential biological controllers (RUANO-ROSA et al., 2010). In the present work, the suppression of $R$. bunodes using this technique did not exceed $35 \%$. Since the analysis of this inhibition is based on the competition for space in Petri dishes, not so high values can be used in the in vitro prospection of biocontrol agents, especially in pairs of species with very different growth rates, as is the case of $R$. necatrix and $R$. bunodes $\mathrm{x}$ Trichoderma (RUANO-ROSA et al., 2010).

The release of volatile compounds allowed the highest inhibition percentage (close to $80 \%$ ) and the lowest mycelial growth of $R$. bunodes, being this mechanism more efficient executed by fungus Trichoderma spp. for the in vitro suppression of this pathogen. Certainly, this fact is related to the exudation of metabolites harmful to the survival of this phytopathogen (GIRONA et al., 2014). Vey et al. (2001) reported that ethylene, hydrogen cyanide, aldehydes and ketones are the major compounds produced by antagonistic fungal species that play an important role in the biocontrol of plant diseases. Several authors verified inhibitory responses by the action of Trichoderma spp. in the mycelial growth of different Rosellinia species (SZTEJNBERG et al., 1987) (RUANOROSA; LÓPEZ-HERRERA, 2009) (RUANO-ROSA et al., 2010).

The release of nonvolatile compounds by Trichoderma was less efficient in the in vitro suppression of $R$. bunodes, when compared to the other procedures used in this research. This can be evidenced by the lack of stimulation of the control activity, which can be attributed to the absence of direct contact between pathogen and antagonist in cultures developed with the interposition of cellophane. However, positive results were reported by Ruano-Rosa et al. (2010) using this technique; of the 30 isolates of Trichoderma spp. tested, 16 produced nonvolatile metabolites harmful to the establishment of R. necatrix. Ruano-Rosa and López-Herrera (2009) also showed that Trichoderma virens isolates caused total inhibition of the growth of $R$. necatrix by the emission of nonvolatile compounds.

In the greenhouse test, poplar seedlings planted 14 days after substrate infestation with $R$. bunodes and Trichoderma asperellum (T3) showed the lowest disease incidence. This response may be related to the longer exposure time between the antagonist agent and the pathogen in the substrate, without the presence of the host, which generates a competitive interaction by specific resources, such as water, nutrients, space and light. In addition, these conditions may stimulate hyperparasite relationships between microorganisms (VINALE et al., 2008 ), leading to a reduction in the density of $R$. bunodes inoculum due to changes in disease-determining factors, such as growth, infectivity and aggressiveness (PARIAUD et al., 2009).

The inhibition process begins with the chemotrophic growth of Trichoderma spp. in response to some stimulus released by the host fungus, culminating in hyphae folding (VINALE et al., 2008). This intimate relationship between pathogen and antagonist is considered a prime factor for the release of hydrolytic enzymes by the hyperparasite, causing the degradation of the host fungus cell wall, facilitating penetration. Another cause of this behavior may be related to the exudation of secondary metabolites by Trichoderma spp., deleterious to the growth of the pathogen in the substrate, confirming responses in in vitro assays.

Therefore, the results of this research show differences regarding the aggressiveness of R. bunodes isolates and the possibility of using biological control in poplar plantations infected by this fungus as an alternative to conventional control methods. Application of antagonistic agents in regions with high Rosellinia root rot incidence may be an option to try to reduce the inoculum potential, since the eradication of infected plants alone is not sufficient. Another aggravating factor is the non-existence of phytosanitary products registered for this pathosystem in Brazil, making it difficult to control this disease. In addition, chemical control for Rosellinia root rot is reported as inefficient (SCHENA et al., 2008) and alternative techniques, such as soil solarization, can only be used in small areas where climatic conditions are favorable (SZTEJNBERG et al., 1987). Further studies should be carried out as a means of promoting the use of biocontrol in the forest sector aiming at a more sustainable agroecosystem.

\section{CONCLUSIONS}

- Rosellinia bunodes isolates differed regarding aggressiveness in poplar.

- The use of biological control with Trichoderma spp. is considered efficient in reducing the in vitro mycelial growth of Rosellinia bunodes. 
- The application of Trichoderma asperellum in substrate infested with Rosellinia bunodes reduced the disease intensity and the longer the exposure time between pathogen and antagonist, the better the efficiency in the control of Rosellinia bunodes in poplar.

\section{ACKNOWLEDGEMENTS}

This study was financed in part by the Coordenação de Aperfeiçoamento de Pessoal de Nível Superior - Brasil (CAPES) - Finance Code 001. The second and third authors received research fellowship from National Council for Scientific and Technological Develop ment (CNPq)/Brazil.

\section{REFERENCES}

DOORNBOS, R. F.; LOON, L. C.; BAKKER, P. A. H. M. Impact of root exudates and plant defense signaling on bacterial communities in the rhizosphere. Agronomy for Sustainable Development, Dijon, v. 32, n.1, p. 227 $243,2011$.

EDGINTON, L. V.; KNEW, K. L.; BARRON, G. L. Fungitoxic spectrum of benzimidazole compounds. Phytopathology, Saint Paul, v. 62, n. 7, p. 42 - 44, 1971.

FRY, W. Quantification of general resistance of potato cultivars and fungicide effects for integrated control of potato late blight. Phytopathology, Saint Paul, v. 68, p. 1650 - 1655, 1978.

GIRONA, I. A.; RUANO-ROSA, D.; LORITO, M. LÓPEZ-HERRERA, C. J. Effect of metabolites from different Trichoderma strains on the growth of Rosellinia necatrix, the causal agent of avocado white root rot. European Journal of Plant Pathology, London, v. 140, n. 2, p. 385 - 397, 2014.

KUMAR, S. Trichoderma: A biological weapon for managing plant diseases and promoting sustainability. International Journal of Agricultural Sciences and Veterinary Medicine, London, v. 1, n. 3, p. 1 - 18, 2013.

LEHNER, M. S.; LIMA, R. C.; CARNEIRO, J. E. S.; PAULA JÚNIOR, T. J.; VIEIRA, R. F.; MIZUBUTI, E. S. G. Similar aggressiveness of phenotypically and genotypically distinct isolates of Sclerotinia sclerotiorum. Plant Disease, Ames, v. 100, n. 2, p. 360 - 366, 2016.

MARIANO, R. L. R. Métodos de seleção in vitro para o controle microbiológico de patógenos de plantas. In: LUZ, W. C. da; FERNANDES, J. M. C.; PRESTES, A. M.; PICININI, E. C. (Ed.) Revisão Anual de Patologia de Plantas, Passo Fundo, v. 1, p. 369 - 409, 1993.

MAY DE MIO, L. L.; AMORIM, L. Doenças do álamo. Floresta, Curitiba, v. 30, n. 1, p. 139 - 153, 2000.

MAY DE MIO, L. L.; RUARO, L. Métodos de avaliação da ferrugem do álamo e eficiência de fungicidas no seu controle. Revista Árvore, Viçosa, v. 32, n. 5, p. 837 - 844, 2008.

MICHEREFF, S. J.; MENEZES, M.; MARIANO, R. L. R. Antagonismo de espécies de Trichoderma sobre Colletotrichum graminicola, agente da antracnose do sorgo em condições de laboratório. Summa Phytopathologica, Jaguariúna, v. 19, n. 1, p. 14 - 17, 1993.

MURALI SANKAR, P.; VANITHA, S.; KAMALAKANNAN, A.; ANANTHA, RAJU, P.; JEYAKUMAR, P. Trichoderma asperellum isolate CTs6 from Ramachandrapuram 18S ribosomal RNA gene, partial sequence;internal transcribed spacer 1, 5.8S ribosomal RNA gene, and internal transcribed spacer 2, complete sequence, and 28S ribosomal RNA gene, partial sequence. Plant Pathology, 2018.

PASINI, L.; PRODORUTTI, D.; PASTORELLI, S.; PERTOT, I. Genetic diversity and biocontrol of Rosellinia necatrix infecting apple in Northern Italy. Plant Disease, Ames, v. 100, n. 2, p. 444 - 452, 2016.

PARIAUD, B.; RAVIGNÉ, V.; HALKETT, F.; GOYEAU, H.; CARLIER, J.; LANNOU, C. Aggressiveness and its role in the adaptation of plant pathogens. Plant Pathology, Seul, v. 58, n. 3, p. 409 - 429, 2009.

R DEVELOPMENT CORE TEAM. R: a language and environment for statistical computing. R Foundation for Statistical Computing, Vienna, 2013. Available in: <http://www.R-project.org/> Access in: 02/01/2018.

RUANO-ROSA, D.; LÓPEZ-HERRERA, C. J. Evaluation of Trichoderma spp. as biocontrol agents against avocado white root rot. Biological Control, San Diego, v. 51, n. 1, p. 66 -71, 2009.

RUANO ROSA, D.; DEL MORAL NAVARRETE, L.; LOPEZ HERRERA, C. J. Selection of Trichoderma spp. isolates antagonistic to Rosellinia necatrix. Spanish Journal of Agriculture Research, Madrid, v. 8, n. 4, p. 1084 $-1097,2010$.

FLORESTA, Curitiba, PR, v. 49, n. 3, p. 439 - 448, jul/set 2019

Kleina, H. T. et.al.

ISSN eletrônico 1982-4688

DOI: $10.5380 /$ rf.v49 i3.59075 
SAITO, L. R.; SALES, L. L. S. R.; MARTINCKOSKI, L.; ROYER, R.; RAMOS M. S.; REFFATTI, T. Aspectos dos efeitos do fungo Trichoderma spp. no biocontrole de patógenos de culturas agrícolas. Applied Research \& Agrotechnology, Guarapuava, v. 2, n. 3, p. 203 - 208, 2009.

SANTOS, A. F. dos; MACHADO, E. B. Controle químico da ferrugem do álamo. Comunicado Técnico 253. Embrapa Florestas, ISSN 1517-5030. Colombo, 2010.

SANTOS, A. F. dos; MACHADO, E. B.; STANOSZ, G. R.; SMITH, D. R. Primeiro relato da ocorrência de Septoria musiva em álamo no Brasil. Tropical Plant Pathology, Brasília, v. 35, n. 1, p. 052 - 053, 2010.

SANTOS, A. F.; THOMAZI, H.; DUARTE, H. S. S.; MACHADO, E. B.; TESSMANN, D. J. First report of root rot caused by Rosellinia bunodes on a poplar species (Populus deltoides) in Brazil. Plant Disease, Ames, v. 101, n. 4, p. 642, 2017.

SHANER, G.; FINNEY, R. E. The effect of nitrogen fertilization on the expression of slow-mildewing resistance in knox wheat. Phytopathology, Saint Paul, v. 67, n. 1, p. 1051 - 1056, 1977.

SCHENA, L.; NIGRO, F.; IPPOLITO, A. Integrated management of Rosellinia necatrix root rot on fruit tree crops. In: CIANCIO, A.; MUKERJI, K. G. Integrated Management of Plant Pests and Diseases. Dordrecht: Ed. Springer eBook, 2008, 419 p.

SIVANeSAN, A.; HOLlidAY, P. CMI Description of Pathogenic Fungi and Bacteria: Rosellinia necatrix, Kew: Commonwealth Mycological Institute, v. 352, p. 1 - 2, 1972.

SZTEJNBERG, A.; FREEMAN, S.; CHET, I.; KATAN, J. Control of Rosellinia necatrix in soil and in apple orchard by solarization and Trichoderma harzianum. Plant Disease, Ames, v. 71, n. 1, p. 365 - 369, 1987.

VEY, A.; HOAGLAND, R. E.; BUTT, T. M. Toxic metabolites of fungal biocontrol agents. In: BUTT T. M.; JACKSON, C. Fungi as Biocontrol Agents: Progress, Problems and Potential. Bristol: CAB International, 2001, $390 \mathrm{p}$.

VINALE, F.; SIVASITHAMPARAM, K.; GHISALBERTI, E. L.; MARRA, R.; WOO, S. L.; LORITO, M. Trichoderma-plant-pathogen interactions. Soil Biology \& Biochemistry, Elmsford, v. 40, n. 1, p.1 - 10, 2008.

WHITE, T. J.; BRUNS, T.; LEE, S.; TAYLOR, J. Amplification and direct sequencing of fungal ribosomal RNA genes for phylogenetics. In: INNIS, M. A.; GELFAND, D. H.; SNINSKY, J. J.; WHITE, T. J. PCR Protocols: A Guide to Methods and Applications. San Diego: Academic Press, 1990, 482 p. 